\title{
Evaluation of Antioxidant Activity and Phytochemical Screening of Leaves, Barks, Stems and Fruits of Alphitonia philippinensis (Rhamnaceae) From Brunei Darussalam
}

\author{
Jamiuddin Ahmed ${ }^{1,3, *}$, Kamariah Abu Salim ${ }^{1}$, Linda B.L. Lim², Abdalla Mohamed Jama'
}

Jamiuddin Ahmed ${ }^{1,3, *}$, Kamariah Abu Salim ${ }^{1}$, Linda B.L. Lim², Abdalla Mohamed Jama ${ }^{1}$

${ }^{1}$ Environmental and Life Sciences, Faculty of Science, Universiti Brunei Darussalam, Tungku Link Road, Bandar Seri Begawan BE 1410, BRUNEI DARUSSALAM.

${ }^{2}$ Chemical Sciences, Faculty of Science, Universiti Brunei Darussalam, Tungku Link Road, Bandar Seri Begawan BE 1410, BRUNEI DARUSSALAM.

${ }^{3}$ Department of Pharmacy, Noakhali Science and Technology University,

BANGLADESH.

\section{Correspondence}

\section{Jamiuddin Ahmed}

Environmental and Life Sciences, Faculty of Science, Universiti Brunei Darussalam, Tungku Link Road, Bandar Seri Begawan BE 1410, BRUNEI DARUSSALAM;

Department of Pharmacy, Noakhali Science and Technology University, BANGLADESH.

E-mail: ajami_ju@yahoo.com

History

- Submission Date: 10-05-2019;

- Review completed: 20-05-2019;

- Accepted Date: 24-05-2019.

\section{DOI : 10.5530/pj.2019.11.151}

Article Available online http://www.phcogj.com/v11/i5

\section{Copyright}

(C) 2019 Phcogj.Com. This is an openaccess article distributed under the terms of the Creative Commons Attribution 4.0 International license.

\begin{abstract}
Phytochemical screening of Alphitonia philippinensis extracts revealed the presence of cardiac glycosides, tannins, saponins and steroids in different plant parts. Total phenolic content (TPC), total flavonoid content (TFC) and total flavonol content (TFIC) were measured using spectrophotometric methods where gallic acid and quercetin were the standards. Antioxidant activity of extracts was assessed using 1,1-diphenyl-2-picrylhydrazyl (DPPH), 2,2-azino-bis(3ethylbenzothiazoline-6-sulfonic acid) (ABTS), free radical scavenging and ferric reducing antioxidant power (FRAP) assays using ascorbic acid and trolox were used as standards. Among the four different crude methanol extracts studies, leaves showed highest antioxidant capacity. $\mathrm{EC}_{50}$ values of the leaves extract from DPPH and ABTS method found 32 and 45 $\mu \mathrm{g} / \mathrm{mL}$ respectively. The higher antioxidant activity of the leaves extract could be correlated with the presence of higher total phenolic content, total flavonoid, and total flavonol contents. According to antioxidant contents and assay results leaves extract possesses highest antioxidant property following fruits, barks and stems
\end{abstract}

Key words: A philippinensis, Phytochemical investigation, Total phenolic contents, Antioxidant property.

\section{INTRODUCTION}

Throughout history, humans have relied on nature to manage their basic needs for food, shelter, garments, transportation, fertilizers, medicines and essence. Numerous medicines have been derived from natural sources for the treatment of various types of diseases in humans and animals from the very beginning of human civilization and most of them come from plants. These plantbased treatments play a vital role in many health care systems. The World Health Organization (WHO) reported that approximately $80 \%$ of the world's inhabitants rely mainly on traditional medicines for their primary health care. ${ }^{1,2}$ Plants contain a wide range of secondary metabolites and phytochemicals such as phenols, flavonoids, steroids, tannins, anthraquinones, saponins, nitrogen compounds (alkaloids, amines, and betalains), terpenoids and many other endogenous -molecules. ${ }^{3-5}$ Many scientific reports provide evidence for their antioxidant, antimicrobial antiinflammatory, analgesic, antipyretic, anticancer, antitumor, antiviral, antidiabetic, and many others therapeutic values. ${ }^{5-9}$

Free radicals, oxidants, and various reactive oxygen species (ROS) are produced by common essential metabolic processes or from external sources such as cigarette smoking, air pollutants, ozone, industrial chemicals, and exposure to $\mathrm{X}$-rays. Free radicals are liable to generate a large number of diseases including cardiovascular disease, neural disorders (Alzheimer's disease, Parkinson's disease, muscular dystrophy), cancer, hypertension, inflammatory diseases (e.g., arthritis, vasculitis, glomerulonephritis), aging and degenerative diseases. The human body possesses a beneficial complex system of natural enzymatic and non-enzymatic antioxidant defenses to protect against the destructive effects of free radicals other oxidants. ${ }^{10-12}$ Synthetic antioxidants such as butylatedhydroxytoluene (BHT), propyl gallate (PG), butylated hydroxyanisole (BHA), and tertbutylhydroquinone are firmly regulated to use in food and medicinal products due to suspicions of their safety and side effects like carcinogenesis and liver damage. ${ }^{13}$ Thus, increased attention is now turned to natural antioxidants such as those of phytochemicals which are relatively safer, more abundant and have the stronger efficiency to scavenge free radicals compared to synthetic antioxidants. ${ }^{14}$

Alphitonia, a genus of the Rhamnaceae family with, approximately 20 species, are available in the tropical regions of Southeast Asia, Polynesia and Oceania. ${ }^{15,16}$ This genus is mainly used in traditional medicine by the inhabitants of Samoa, Fiji, Tahiti, Vanuatu, Tonga, Northern Australia and Brunei Darussalam for coughs, constipation, headaches, stomachaches, menstrual pain, prolapsed rectum after postpartum woman, facilitate childbirth, swelling, fever, earache, cancer, skin diseases (eczema, ecthyma, pityriasis), inflammation, rheumatic pains, ulcer, gastrointestinal and urogenital disorders. ${ }^{16-19}$ Isolation of a range of bioactive compounds were reported from this genus having antioxidant, antimicrobial, cytotoxic, antiulcer, antityrosinase, inhibitions of 
prostaglandin biosynthesis and replication on herpes simplex virus type- $1 . .^{14,16-20}$

Alphitonia philippinensis Braid is vernacularly known by the Malays in Brunei Darussalam as "balik angin". Locally it is used in traditional medicine where its leaves are used for the treatment of stomachaches and herbal bath for women to regain strength after delivery. Freshly cut and separated bark and stem of the plant produce a pleasant aromatic smell. Isolated triterpenoids (lupeol, betulinic acid, ceanothic acid) and flavonoid glycosides (derivatives of quercetin and isorhamnetin) from the stems of $A$. philippinensis exhibited cytotoxicity against human PC-3 cells and hepatoma HA22T cells. Replication of herpes simplex virus type- 1 was inhibited in trial by some of these compounds. ${ }^{20}$

This current study was designed to screen methanolic extracts of leaves, stems, barks and fruits of this plant for phytochemicals, and to determine their total phenolic, flavonoid, flavonol contents and antioxidant activity. To date and to the best of our knowledge, no report has been published on the phytochemical screening and antioxidant activity of $A$. philippinensis. This study will, therefore, provide further insight into the potential of $A$. philippinensis as a medicinal plant.

\section{MATERIALS AND METHODS}

\section{Chemicals and reagents}

All the chemicals and reagents used in this study were of analytical grade. Ascorbic acid, 2,4,6-tris(2-pyridyl)-s-triazine (TPTZ), 2,2'-azinobis(3-ethylbenzothiazoline-6-sulfonic acid) (ABTS), 1,1-diphenyl-2picrylhydrazyl (DPPH), 6-hydroxy-2,5,7,8-tetramethylchroman-2carboxylic acid (trolox), quercetin dihydrate, gallic acid, anhydrous sodium carbonate, aluminum trichloride, potassium acetate, sodium acetate, ferric chloride hexahydrate $\left(\mathrm{FeCl}_{3} \cdot 6 \mathrm{H}_{2} \mathrm{O}\right)$, Folin Ciocalteu reagent, Mayers's reagent, Dragendorff's reagent, mercuric chloride, potassium iodide, iodine were purchased from Sigma-Aldrich Chemie (Steinheim, Germany). Ethanol, methanol, hydrochloric acid ( $\mathrm{HCl})$, sulfuric acid $\left(\mathrm{H}_{2} \mathrm{SO}_{4}\right)$, chloroform, ammonia, glacial acetic acid, sodium hydroxide $(\mathrm{NaOH})$ were purchased from Merck (Germany) and potassium peroxodisulfate from Fluka (Germany).

\section{Plant materials}

The leaves, stems, barks and fruits of A. philippinensis were collected from a slope of a vegetated roadside area in Kampung Katok, situated in the Brunei-Muara District, Brunei Darussalam in May 2015. The species was identified by Dr. Kamariah Abu Salim (Universiti Brunei Darussalam) and authenticated by comparing it with a reference specimen at the National Herbarium of Brunei Darussalam (BRUN). A voucher specimen (No. JA-1) was prepared and deposited in the Universiti Brunei Darussalam Herbarium (UBDH).

\section{Preparation of methanolic extracts}

Different parts of the plant (leaves, stems, barks and fruits) were separated, rinsed, and cut into small pieces. The plant materials were dried in open air at $25^{\circ} \mathrm{C}$ under the shade and then freeze dried under vacuum for two days. All the four parts of the plants were ground into fine powder using a laboratory mill (Model: MF $10 \mathrm{~B}, \mathrm{IKA}$ ). The powder $(35 \mathrm{~g})$ was placed in a thimble and extracted with $250 \mathrm{~mL}$ of absolute methanol using a soxhlet apparatus for 6-8 h. The solvent was then evaporated under reduced pressure at $50^{\circ} \mathrm{C}$ using a rotary evaporator (BuchiRotavapor, Model: R-114). The crude extracts were dried in a freeze dryer until a constant mass was obtained and stored at $4^{\circ} \mathrm{C}$ in the dark. All the measurements for total phenolic content (TPC), total flavonoid content (TFC) and total flavonol content (TFlC) and others of experiments were expressed in gram of freeze dried powder sample which is converted from the gram freeze-dried crude extract.
The percentage yield of methanolic extract for each plant part was calculated using the equation (1) as shown below:

Yield $(\%)=$ A/B X 100

Here, $\mathrm{A}=$ Weight of freeze-dried crude extract $(\mathrm{g})$

$\mathrm{B}=$ Freeze dried powder sample $(\mathrm{g})$

\section{Phytochemical screening}

All the plant extracts were subjected to a variety of phytochemical tests following the methods as described by Evans ${ }^{5}$ and Sofowora ${ }^{8}$ to detect the presence of tannins, saponins, steroids, alkaloids, cardiac glycosides, anthraquinones, and terpenoids. The presence or absence of a particular phytochemical was confirmed by color change or precipitate formation by visual observation.

\section{Determination of phenolic compounds}

\section{Determination of TPC}

The total phenolic content was determined using the standard FolinCiocalteu method by Chlopicka et al., with minor modification. ${ }^{21}$ The plant extract $(0.3 \mathrm{~mL}$ of $1 \mathrm{mg} / \mathrm{mL}$ solution) was mixed with the FolinCiocalteu phenol reagent $(2.25 \mathrm{~mL})$ and $6 \%$ sodium carbonate $(2.25$ $\mathrm{mL}$ ) was added after $5 \mathrm{~min}$. The mixture was left to stand for $90 \mathrm{~min}$ at $25^{\circ} \mathrm{C}$ and then the absorbance was measured at $725 \mathrm{~nm}$ using a UV visible spectrophotometer (UV-1800, Shimadzu). Following the same procedure, a standard calibration curve of gallic acid was prepared in the concentration range of $0-200 \mu \mathrm{g} / \mathrm{mL}$. The results were expressed as mg gallic acid equivalents per gram dry weight of powdered plant parts (mg GAE/g DW).

\section{Determination of TFC}

Aluminum chloride colorimetric method by Lin and Tang, ${ }^{22}$ with some modifications, was used to determine the total flavonoid content (TFC) of each of the plant extracts. Quercetin was used as the standard and a calibration curve was prepared in the concentration range $0-200 \mu \mathrm{g} /$ $\mathrm{mL}$. Both standard and extract $(0.5 \mathrm{~mL})$ were placed in different test tubes and to each $10 \%$ aluminum chloride $(0.1 \mathrm{~mL}), 1 \mathrm{M}$ potassium acetate $(0.1 \mathrm{~mL}), 80 \%$ methanol $(1.5 \mathrm{~mL})$ and distilled water $(2.8 \mathrm{~mL})$ were added and mixed. Likewise, a blank was prepared in the same manner but distilled water $(0.5 \mathrm{~mL})$ was used instead of the sample or standard and aluminum chloride was also replaced by distilled water in the same amount. All the tubes were incubated at $25^{\circ} \mathrm{C}$ for 30 min, and the absorbance was measured at $415 \mathrm{~nm}$ using a UV-visible spectrophotometer. The concentration of flavonoid was expressed as mg quercetin equivalents per gram dry weight of powdered plant parts (mg QE/g DW).

\section{Determination of TFIC}

Total flavonol content (TFlC) was determined using the aluminum chloride colorimetric method as described by Kumaran and Karunakaran, ${ }^{23}$ with minor modification. A standard calibration curve was prepared using quercetin in the concentration range of $0-35 \mu \mathrm{g} / \mathrm{mL}$. The plant extract $(1 \mathrm{~mL})$ and standard solution $(1 \mathrm{~mL})$ were placed in different test tubes and then $2 \%$ aluminum chloride $(1 \mathrm{~mL}), 5 \%$ sodium acetate $(3 \mathrm{~mL})$ were added and mixed well. The reaction mixture was then centrifuged at $3000 \mathrm{rpm}$ for $20 \mathrm{~min}$ at $25^{\circ} \mathrm{C}$ and the absorbance of standard and sample were measured at $440 \mathrm{~nm}$ using a UV-visible spectrophotometer. The concentration of flavonol was expressed as mg quercetin equivalents per gram dry weight of powdered plant parts (mg QE/g DW). 


\section{Evaluation of antioxidant activity}

\section{$E C_{50}$ value determination}

DPPH (1,1-Diphenyl-2-picrylhydrazyl) free radical-scavenging assay: 1,1-Diphenyl-2-picrylhydrazyl (DPPH) free radical scavenging capacity of the methanolic extracts (leaves, barks, stems and fruits) was determined using the assay method as described by Abdul-Wahab et al. ${ }^{24}$ with minor modifications. A methanol solution of $0.1 \mathrm{mM} \mathrm{DPPH}$ was prepared as well as all the extracts in different concentrations ranging from 1-200 $\mu \mathrm{g} / \mathrm{mL}$. Trolox and ascorbic acid were used as the standards and a series of these standards were prepared in the concentration range of $1-12 \mu \mathrm{g} / \mathrm{mL}$. The free radical scavenging activity was expressed as $\mathrm{EC}_{50}$ (effective concentration in $\mu \mathrm{g} / \mathrm{mL}$ of sample or standard which reduces the absorbance of DPPH by $50 \%$ as calculated from the standard graph).

The extracts (leaves, barks, stems and fruits; $1.5 \mathrm{~mL}$ each) and standard solutions $(1.5 \mathrm{~mL})$ were placed in different test tubes. The DPPH solution $(1.5 \mathrm{~mL})$ was added to each of the test tubes. The reaction was allowed to react in the dark for $30 \mathrm{~min}$ and its absorbance was measured at $517 \mathrm{~nm}$ by using a UV- visible spectrophotometer. The percentage (\%) inhibition of both samples and standards were calculated for each concentration and plotted in graphs of percentage inhibition against concentration. The $\mathrm{EC}_{50}$ values of standards and samples were calculated from these graphs The percentage inhibition was calculated according to the equation (2) as shown below

Inhibition $(\%)=\mathrm{Ab}-\mathrm{At} / \mathrm{Ab} \mathrm{X} 100$

Here, $\mathrm{Ab}=$ Absorbance of blank $(\mathrm{Ab})$

At $=$ Absorbance of test sample(At)

\section{ABTS radical scavenging assay}

2,2'-Azino-bis(3-ethylbenzothiazoline-6-sulfonic acid) (ABTS) free radical scavenging assay was carried out according to the method as described by Lobo et al., ${ }^{25}$ with minor modifications. Methanolic extracts (leaves, barks, stems and fruits) were prepared at different concentrations ranging from 5 to $200 \mu \mathrm{g} / \mathrm{mL}$. Trolox and ascorbic acid were used as the standards, and a series of standards were prepared in the concentration range from 1 to $12 \mu \mathrm{g} / \mathrm{mL}$. The ABTS stock solution was prepared by mixing $7 \mathrm{mM}$ ABTS solution and $2.4 \mathrm{mM}$ potassium persulfate solution in the ratio of $1: 1$ and followed by incubation at $25^{\circ} \mathrm{C}$ in the dark for $12 \mathrm{~h}$. The working solution was prepared by diluting the resulting solution $(1 \mathrm{~mL})$ with methanol $(60 \mathrm{~mL})$ until an absorbance of $0.70 \pm 0.01$ arbitrary units at $\lambda=734 \mathrm{~nm}$ using a UVvisible spectrophotometer. All the extracts and standards were then allowed to react with the ABTS working solution at a ratio of $1: 1$ for 30 min at $25^{\circ} \mathrm{C}$ in the dark and the absorbance was measured at $\lambda=734$ $\mathrm{nm}$. The free radical scavenging activity was expressed as $\mathrm{EC}_{50}$ (effective concentration in $\mu \mathrm{g} / \mathrm{mL}$ of sample extract or standard that reduces the absorbance of ABTS by $50 \%$ calculated from the standard graph). The percentage (\%) inhibition of samples and standards were calculated for each concentration using equation (II) above. Graphs of percentage inhibition against concentration were plotted and the $\mathrm{EC}_{50}$ values of the test sample and two standards were calculated from these graphs.

\section{FRAP assay}

The assay was conducted according to the methods as described by Thiapong et al., ${ }^{26}$ with minor modifications. The FRAP reagent was freshly prepared by mixing $300 \mathrm{mM}$ sodium acetate buffer $(100 \mathrm{~mL}), 10$ $\mathrm{mM}$ TPTZ solution $(10 \mathrm{~mL})$ and $20 \mathrm{mM} \mathrm{FeCl}_{3} \cdot 6 \mathrm{H}_{2} \mathrm{O}(10 \mathrm{~mL})$ solution and kept warmed at $37^{\circ} \mathrm{C}$ until used. Trolox and ascorbic acid were used as the standards and the calibration curve for each was prepared in the range $1-250 \mu \mathrm{g} / \mathrm{mL}$.
The extracts (leaves, barks, stems and fruits; $150 \mu \mathrm{L}$ each) and the standard solution $(150 \mu \mathrm{L})$ were allowed to react with the FRAP solution $(2850 \mu \mathrm{L})$ in different test tubes for $30 \mathrm{~min}$ in the dark at $25^{\circ} \mathrm{C}$. The increase in absorbance due to the reduction of $\mathrm{Fe}^{3+}-\mathrm{TPTZ}$ to $\mathrm{Fe}^{2+}$ TPTZ (ferrous-tripyridyltriazine complex) was measured at $593 \mathrm{~nm}$ by using a UV-visible spectrophotometer. The results were expressed as $\mathrm{mg}$ of trolox equivalent and $\mathrm{mg}$ of ascorbic acid equivalent per gram dry weight of powdered plant parts (mg TE/g DW and mg AAE/g DW), which were estimated from standard graphs.

\section{ABTS assay}

The ABTS assay methods as described by Thiapong et al., ${ }^{26}$ was used to determine the antioxidant activity of the extracts in terms of weight of trolox and ascorbic acid equivalents. The ABTS stock solution was prepared by mixing an equal amount of $7.4 \mathrm{mM}$ ABTS solution and $2.6 \mathrm{mM}$ potassium persulfate solution followed by incubation at $25^{\circ} \mathrm{C}$ in the dark for $12 \mathrm{~h}$. The working solution was prepared by diluting the resulting solution $(1 \mathrm{~mL})$ with methanol $(20 \mathrm{~mL})$ until reach at an absorbance of $1.1 \pm 0.05$ arbitrary units at $\lambda=734 \mathrm{~nm}$ using a UVvisible spectrophotometer. A series of standards were prepared in the concentration range of $1-125 \mu \mathrm{g} / \mathrm{mL}$.

Standard solution $(150 \mu \mathrm{L})$ and sample extract $(150 \mu \mathrm{L})$ were placed in different test tubes and then the ABTS working solution $(2850 \mu \mathrm{L})$ was added to each oe. All the mixtures were allowed to react in the dark for $30 \mathrm{~min}$, and their absorbance was measured at $734 \mathrm{~nm}$ by using a UV - visible spectrophotometer. The percentage (\%) inhibition of the two standards and extracts were calculated for each concentration and plotted in graphs of percentage inhibition against concentration. The results were expressed as mg of trolox or ascorbic acid equivalent per gram dry weight of powdered plant parts (mg TE/g DW and mg AAE/g DW), which were estimated from standard graphs.

\section{Statistical analyses}

All the experiments were carried out in triplicates and the results were expressed as means \pm standard deviations (unless otherwise stated). The results of antioxidants contents and antioxidant activity were analyzed using correlation and regression of Microsoft Excel 2007. Statistical analyses were done using SPSS software version 20.0 (IBM Corp., Armonk, NY, USA). Analysis of variance (ANOVA), KruskallWallis, Tukey's HSD, and independent sample t-tests were applied for comparisons of means and medians, where significant differences were considered at $\mathrm{P}<0.05$. The Pearson's correlation coefficient test was done using SPSS to verify inter-relationships between TPC, TFC, TFIC, and antioxidant activity.

\section{RESULTS}

\section{Yield of crude extracts}

The extraction yields of crude methanolic extracts of leaves, barks, stems, and fruits were $34.60,12.70,3.18,18.81 \%$ per $g$ of the freezedried weight of the sample, respectively, and they differed significantly $(P<0.05)$ from each other (Figure 1$)$. Thus, ranked from highest to lowest, the $\%$ yield is in the order of leaves $>$ fruits $>$ barks $>$ stems.

\section{Phytochemical screening}

The phytochemical screening of crude methanolic extracts of the leaves, barks, stems and fruits of $A$. philippinensis showed the presence of some secondary metabolites such as steroids, tannins, saponins and cardiac glycosides (Table 1). Cardiac glycosides and steroids were detected in all plant parts of the A. philippinensis. Saponins were detected in leaves and barks whereas tannins were only found in leaves. Alkaloids and anthraquinone glycosides were absent from all plant parts. 


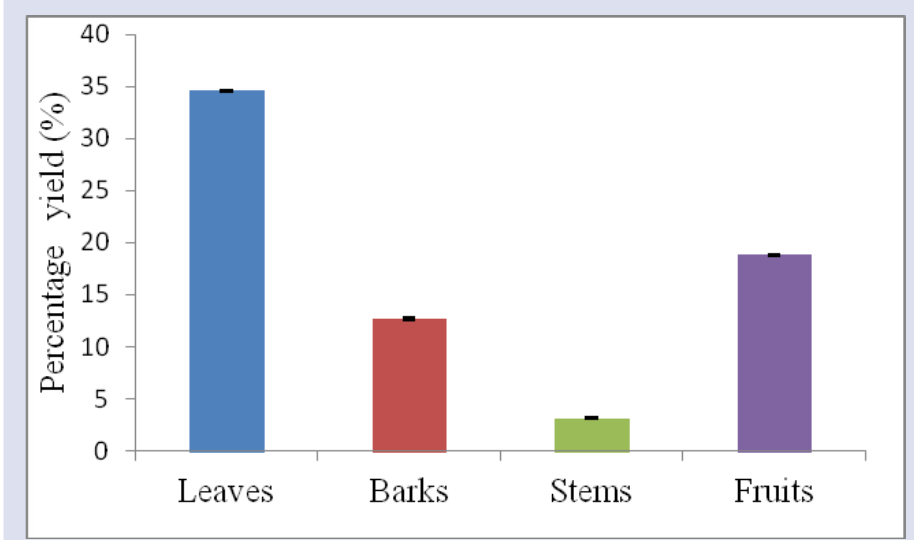

Figure 1: Percentage yield (mean, $\mathrm{N}=3$ ) of methanolic extracts of leaves, barks, stems and fruits of $A$. philippinensis. The bars represent standard errors of means.

Table 1: Phytochemicals detected in methanolic extracts of leaves, barks, stems and fruits of $A$. philippinensis.

\begin{tabular}{|c|c|c|c|c|c|}
\hline Phytochemical & Test performed & Leaves & Barks & Stems & Fruits \\
\hline \multirow{3}{*}{ Alkaloids } & Dragendorff's Test & - & - & - & - \\
\hline & Mayer's Test & - & - & - & - \\
\hline & Wagner's Test & - & - & - & - \\
\hline \multirow{2}{*}{ Steroids/terpenoids } & Salkowski Test & + & + & + & + \\
\hline & Libermann Burchard Test & + & + & + & + \\
\hline Tannins & Ferric chloride test & + & - & - & - \\
\hline Saponins & Frothing test & + & + & - & - \\
\hline \multirow[t]{2}{*}{ Glycosides } & $\begin{array}{l}\text { Anthraquinone } \\
\text { Glycosides } \\
\text { (Borntrager's Test) }\end{array}$ & - & - & - & - \\
\hline & $\begin{array}{l}\text { Cardiac Glycoside } \\
\text { (Keller-Killiani Test) }\end{array}$ & + & + & + & + \\
\hline
\end{tabular}

+ Present, - absent

\section{Total phenolic, flavonoid, and flavonol contents}

The total phenolic, flavonoid and flavonol contents of the extracts of $A$. philippinensis varied significantly $(P<0.05)$ with different plant parts (Table 2). Among the four plant parts (leaves, stems, barks and fruits), leaves exhibited the highest amount of total phenolic, flavonoid and flavonol contents, followed by fruits, barks and stems. The TPC was also the highest of all four plant parts, followed by the TFC and TFlC.

\section{Evaluation of antioxidant activity}

The antioxidant activities of extracts of A. philippinensis were determined using three different assays i.e. DPPH, ABTS and FRAP, as well as two different standards, trolox and ascorbic acid (Tables 3 and 4). Different assays and standards were used to evaluate the antioxidant activities of samples since a single method can detect only a very specific antioxidant from its large and many varieties and cannot cover the whole antioxidant activity measurement of a sample. The delocalization of the spare electron of DPPH makes it a stable free radical. When DPPH accepts an electron from the antioxidant, its deep purple color changes to yellow. The ABTS is also a stable bluegreen free radical and losses its color by the addition of an antioxidant. The FRAP method measures the ability of antioxidants based on the reduction of the complex of ferric ion and TPTZ to the ferrous form at low $\mathrm{pH}$. All these three methods are simple, inexpensive and reliable to measure antioxidant activity.

\section{Correlation between antioxidant contents and antioxidant activity}

According to the Pearson's correlation analysis, correlation is positively high if $0.61 \leq r \leq 0.97$ and negatively high if $-0.61 \leq r \leq-0.97 .{ }^{26,27}$ Negative value signifies that the relations between two parameters are inversely correlated. In this study we determined the correlations between antioxidants contents (TPC, TFC and TFlC) of leaves, barks, stems and fruits extracts of A. philippinensis and their activities detected by different in vitro antioxidant assays (ABTS, FRAP and DPPH). The results are presented in Tables $5 \mathrm{~A}$ to $5 \mathrm{D}$.

\section{DISCUSSION}

Extraction yields of the different plant parts of this study were compared with some publish data and previous report showed that extraction of $A$. philippinesis stem in ethanol using maceration technique gave $1.50 \%,{ }^{20}$ a value almost half of what was obtained in this study. Although there was no previous report on the leaves of A. philippinesis, a search through literature revealed that the leaves of $A$. xerocarpus gave a percentage yield of $34.67 \%$ in $80 \%$ methanol by successive maceration technique, ${ }^{16}$ a result similar to what was found in this study. Percentage yields of fruits of A. neocaledonica by maceration technique was higher $(29.54 \%$ in water) and lower ( $8.67 \%$ in $n$-butanol) than this study. ${ }^{14}$ To date, no published data of percentage yield was found on barks of any species of Alphitonia. However, when compared to Rhamnus alaternus (6.30\% in methanol and $16.60 \%$ in water by maceration) of the same Rhamnaceae family $^{28}$ the percentage yield of the barks of A. philippinensis was higher by approximately two fold with methanol extract but close to water extract. Percentage yields of different plant species may vary due to the difference in genetic makeup of the plants, sampling location, harvesting time, extraction method and solvent used in the extraction. Different solvents have different polarity and hence have the ability to extract different compounds, giving different percentage yields of extracts. Sometimes the aqueous solution of organic solvents 
Ahmed, et al: Evaluation of Antioxidant Activity and Phytochemical Screening of Leaves, Barks, Stems and Fruits of Alphitonia philippinensis (Rhamnaceae) From Brunei Darussalam

Table 2: Total phenolic, flavonoid and flavonol contents of methanolic extracts of leaves, barks, stems and fruits of $A$. philippinensis.

\begin{tabular}{|c|c|c|c|}
\hline Plant parts & Total phenolic content (mg a GAE /g) & Total flavonoid content (mg ${ }^{\mathrm{b}} \mathrm{QE} / \mathrm{g}$ ) & Total flavonol content ( $\mathrm{mg}{ }^{\mathrm{b}} \mathrm{QE} / \mathrm{g}$ ) \\
\hline Leaves & $25.23 \pm 0.15$ & $9.84 \pm 0.06$ & $4.61 \pm 0.03$ \\
\hline Barks & $6.26 \pm 0.11$ & $0.28 \pm 0.01$ & $0.12 \pm 0.01$ \\
\hline Stems & $1.04 \pm 0.02$ & $0.03 \pm 0.01$ & $0.001 \pm 0.00$ \\
\hline Fruits & $14.17 \pm 0.31$ & $1.06 \pm 0.02$ & $1.82 \pm 0.04$ \\
\hline
\end{tabular}

Values are means $\pm \mathrm{SD}(n=3)$. Mean values were significantly different between columns $(\mathrm{P}<0.05)$. ${ }^{\mathrm{G} A E}$ - gallic acid equivalent, ${ }^{\mathrm{b}} \mathrm{QE}-\mathrm{quercetin}$ equivalent.

Table 3: Comparison of the total phenolic content of methanolic extracts of leaves, barks, stems and fruits of $A$. philippinensis with published data of some medicinal plants.

\begin{tabular}{|c|c|c|}
\hline Plant name and family & Plant part & $\mathrm{TPC}(\mathrm{mg}$ of $\mathrm{GAE} / \mathrm{g})$ \\
\hline \multirow{4}{*}{ A. philippinensis (Rhamnaceae) - this study } & Leaves & 25.23 \\
\hline & Barks & 6.26 \\
\hline & Fruits & 14.17 \\
\hline & Stems & 1.04 \\
\hline \multirow{2}{*}{ Colubrina asiatica (Rhamnaceae) } & Leaves & 12.49 \\
\hline & Stems & 0.86 \\
\hline \multirow{2}{*}{ Etlingera coccinea (Zingiberaceae) } & Leaves & 13.49 \\
\hline & Stems & 7.94 \\
\hline Ginkgo biloba (Ginkgoaceae) & Leaves & 11.55 \\
\hline \multirow{2}{*}{ Goniothalamus velutinus (Annonaceae) } & Barks & 68 \\
\hline & Leaves & 78 \\
\hline Morus alba (Moraceae) & Leaves & 10.94 \\
\hline Zizyphus jujube (Rhamnaceae) & Fruits & 2.52 \\
\hline \multirow{3}{*}{ Zizyphus spina-christi (Rhamnaceae) } & Leaves & 35.85 \\
\hline & Barks & 42.53 \\
\hline & Fruits & 9.63 \\
\hline \multirow{2}{*}{ Zizyphus xylopyrus (Rhamnaceae) } & Leaves & 68.16 \\
\hline & Fruits & 62.62 \\
\hline \multirow{3}{*}{ Ziziphus oxyphylla (Rhamnaceae) } & Leaves & 15.77 \\
\hline & Fruits & 27.61 \\
\hline & Stems & 17.49 \\
\hline Ziziphus mistol (Rhamnaceae) & Fruits & 7.97 \\
\hline Zizyphus lotus (Rhamnaceae) & Fruits & 40.78 \\
\hline
\end{tabular}

Table 4: Antioxidant activities of extracts of different plant parts of $A$. philippinensis determined using ABTS and FRAP assays.

\begin{tabular}{|c|c|c|c|c|}
\hline \multirow{2}{*}{ Plant parts } & \multicolumn{2}{|c|}{ ABTS } & \multicolumn{2}{|c|}{ FRAP } \\
\hline & $\mathrm{mg}^{\mathrm{a}} \mathrm{TE} / \mathrm{g}$ & $\mathrm{mg}{ }^{\mathrm{b}} \mathrm{AAE} / \mathrm{g}$ & $\mathrm{mg}^{\mathrm{a}} \mathrm{TE} / \mathrm{g}$ & $m g{ }^{b} A A E / g$ \\
\hline Leaves & $10.05 \pm 0.05$ & $10.05 \pm 0.05^{*}$ & $10.74 \pm 0.06$ & $9.36 \pm 0.05$ \\
\hline Barks & $0.69 \pm 0.11$ & $0.98 \pm 0.11$ & $1.01 \pm 0.01$ & $1.01 \pm 0.01$ \\
\hline Stems & $0.08 \pm 0.02$ & $0.14 \pm 0.02$ & $0.12 \pm 0.002$ & $0.12 \pm 0.002$ \\
\hline Fruits & $8.45 \pm 0.19$ & $9.83 \pm 0.22^{\star}$ & $7.53 \pm 0.17$ & $3.76 \pm 0.08$ \\
\hline
\end{tabular}

Values are means $\pm \mathrm{SD}(n=3)$, ${ }^{\mathrm{T}} \mathrm{TE}$ trolox equivalent, ${ }^{\mathrm{b}} \mathrm{AAE}$ ascorbic acid equivalent.

Mean values were significantly different between $(\mathrm{P}<0.05)$ columns except that with the asterisk.

also used to facilitate the extraction of phytochemicals that are soluble in water and/or organic solvent. ${ }^{29}$ Similarity of polarity and molecular weight of extraction solvent and extracted chemicals from a given sample have also a good relation. It can be explained with 'like dissolve like' concept. ${ }^{30}$ Therefore, it is quite impossible to extract all types of phenolic compounds from a sample in a single solvent. A research study used five different solvents as hexane, petroleum ether, chloroform, ethyl acetate and methanol for extraction and results revealed that methanol extract contain highest number of Phytochemicals compared to other solvent extracts. ${ }^{31}$ Another two published reports also claimed to have found highest amount of total phenolic content from methanolic extract when compared with some other solvent extracts in different species. ${ }^{32,33}$ In this study, methanol a highly polar solvent was chosen as the extraction solvent to extract more polar compounds as well as phenolic compounds. Extracting all the four plant parts (leaves, barks, stems, and fruits) using the same solvent and extraction method allows easier and consistent comparison of results.

In terms of phytochemical screening study similar secondary metabolites have also been reported in other species of this genus and other genus of this family. For example, fruits of $A$. neocaledonic, leaves of Zizyphus spina-christi, leaves and stem barks of $Z$. mauritiana, were all reported to have similar Phytochemicals. ${ }^{14,34,35}$ These phytochemicals are known to have important traditional and medicinal uses. Crude extracts of plants having cardiac glycosides had been used in ancient time for arrow coatings, homicidal or suicidal aids, rat poison, heart tonics, diuretics and emetics. Modern medicine has also developed drugs to treat congestive heart failure and cardiac arrhythmia from purified plant extracts or synthetic analogues of some of these cardiac glycosides. ${ }^{36-38}$ 
Ahmed, et al: Evaluation of Antioxidant Activity and Phytochemical Screening of Leaves, Barks, Stems and Fruits of Alphitonia philippinensis (Rhamnaceae) From Brunei Darussalam

Table 5(A-D): Pearson's correlation coefficients of (leaves, barks, stems and fruits) of $A$. philippinensis between antioxidant contents (TPC, TFC and TFIC) and their activities detected using different antioxidant assays (ABTS, FRAP and DPPH).

\section{A. Leaves}

\begin{tabular}{|c|c|c|c|c|c|c|c|c|c|}
\hline & aTPC & ${ }^{\text {bTFC }}$ & TF1C & ${ }^{d 1}$ ABTS & $\mathrm{d}^{2}$ ABTS & ${ }^{e 1}$ FRAP & e2FRAP & ${ }^{f} D P P H$ & ${ }^{g}$ ABTS \\
\hline TPC & 1 & & & & & & & & \\
\hline TFC & $0.999^{*}$ & 1 & & & & & & & \\
\hline TF1C & 0.169 & 0.12 & 1 & & & & & & \\
\hline${ }^{\mathrm{d} 1}$ ABTS & 0.801 & 0.83 & 0.454 & 1 & & & & & \\
\hline${ }^{\mathrm{d} 2} \mathrm{ABTS}$ & 0.965 & 0.951 & 0.421 & 0.617 & 1 & & & & \\
\hline${ }^{\mathrm{el}}$ FRAP & $1.000^{*}$ & $1.000^{*}$ & 0.143 & 0.817 & 0.958 & 1 & & & \\
\hline${ }^{\mathrm{e} 2} \mathrm{FRAP}$ & $0.999^{*}$ & $1.000^{* *}$ & 0.12 & 0.83 & 0.951 & $1.000^{*}$ & 1 & & \\
\hline DPPH50 & -0.879 & -0.854 & -0.619 & -0.419 & -0.973 & -0.866 & -0.854 & 1 & \\
\hline ABTS50 & -0.974 & -0.961 & -0.389 & -0.644 & $-.999^{*}$ & -0.967 & -0.961 & 0.964 & 1 \\
\hline
\end{tabular}

\section{B. Barks}

\begin{tabular}{|c|c|c|c|c|c|c|c|c|c|}
\hline & ${ }^{\mathrm{a}} \mathrm{TPC}$ & ${ }^{\mathrm{b}} \mathrm{TFC}$ & 'TF1C & ${ }^{d 1}$ ABTS & ${ }^{d 2}$ ABTS & ${ }^{\mathrm{e}} \mathrm{FRAP}$ & ${ }^{e 2} \mathrm{FRAP}$ & fDPPH & ${ }^{g} \mathrm{ABTS}$ \\
\hline TPC & 1 & & & & & & & & \\
\hline TFC & 0.991 & 1 & & & & & & & \\
\hline TF1C & $0.998^{*}$ & 0.982 & 1 & & & & & & \\
\hline${ }^{\mathrm{d} l}$ ABTS & 0.549 & 0.655 & 0.5 & 1 & & & & & \\
\hline${ }^{\mathrm{d} 2}$ ABTS & 0.549 & 0.655 & 0.5 & $1.000^{* *}$ & 1 & & & & \\
\hline${ }^{\mathrm{e}} \mathrm{FRAP}$ & 0.991 & $1.000^{\star *}$ & 0.982 & 0.655 & 0.655 & 1 & & & \\
\hline${ }^{\mathrm{e} 2} \mathrm{FRAP}$ & 0.991 & $1.000^{* *}$ & 0.982 & 0.655 & 0.655 & $1.000^{* *}$ & 1 & & \\
\hline DPPH50 & $-0.998^{\star}$ & -0.982 & $-1.000^{* *}$ & -0.5 & -0.5 & -0.982 & -0.982 & 1 & \\
\hline ABTS50 & -0.661 & -0.754 & -0.616 & -0.99 & -0.99 & -0.754 & -0.754 & 0.616 & 1 \\
\hline
\end{tabular}

\section{Stems}

\begin{tabular}{|c|c|c|c|c|c|c|c|c|c|}
\hline & ${ }^{\text {aTPC }}$ & ${ }^{\text {bTFC }}$ & TF1C & ${ }^{\mathrm{d} 1} \mathrm{ABTS}$ & ${ }^{\mathrm{d} 2}$ ABTS & ${ }^{\mathrm{e}} \mathrm{FRAP}$ & ${ }^{\text {e2}}$ FRAP & fDPPH & ${ }^{g} \mathrm{ABTS}$ \\
\hline TPC & 1 & & & & & & & & \\
\hline TFC & 0.996 & 1 & & & & & & & \\
\hline TF1C & 0.846 & 0.797 & 1 & & & & & & \\
\hline${ }^{\mathrm{d} l} \mathrm{ABTS}$ & 0.996 & 0.984 & 0.891 & 1 & & & & & \\
\hline${ }^{\mathrm{d} 2} \mathrm{ABTS}$ & 0.908 & 0.941 & 0.545 & 0.866 & 1 & & & & \\
\hline${ }^{\text {el}}$ FRAP & 0.954 & 0.924 & 0.967 & 0.977 & 0.739 & 1 & & & \\
\hline${ }^{\mathrm{e} 2} \mathrm{FRAP}$ & 0.125 & 0.21 & 0.423 & 0.034 & 0.529 & 0.18 & 1 & & \\
\hline DPPH50 & -0.971 & -0.988 & -0.693 & -0.945 & -0.982 & -0.853 & -0.359 & 1 & \\
\hline ABTS50 & -0.805 & -0.853 & -0.365 & -0.748 & -0.98 & -0.589 & -0.689 & 0.924 & 1 \\
\hline \multicolumn{10}{|l|}{ D. Fruits } \\
\hline & ${ }^{\mathrm{a}} \mathrm{TPC}$ & ${ }^{\text {bTFC }}$ & TF1C & ${ }^{d 1}$ ABTS & ${ }^{d 2}$ ABTS & ${ }^{e 1}$ FRAP & ${ }^{e 2} \mathrm{FRAP}$ & fDPPH & ${ }^{g} \mathrm{ABTS}$ \\
\hline TPC & 1 & & & & & & & & \\
\hline TFC & $1.000^{* *}$ & 1 & & & & & & & \\
\hline TF1C & $1.000^{* *}$ & $1.000^{* *}$ & 1 & & & & & & \\
\hline${ }^{d 1}$ ABTS & $1.000^{*}$ & $1.000^{* *}$ & $1.000^{* *}$ & 1 & & & & & \\
\hline${ }^{\mathrm{d} 2} \mathrm{ABTS}$ & $1.000^{*}$ & $1.000^{* *}$ & $1.000^{* *}$ & $1.000^{* *}$ & 1 & & & & \\
\hline${ }^{\mathrm{el}}$ FRAP & $1.000^{* *}$ & $1.000^{\star *}$ & $1.000^{* *}$ & $1.000^{* *}$ & $1.000^{* *}$ & 1 & & & \\
\hline${ }^{\mathrm{e} 2} \mathrm{FRAP}$ & $1.000^{* *}$ & $1.000^{\star *}$ & $1.000^{* *}$ & $1.000^{* *}$ & $1.000^{* *}$ & $1.000^{\star *}$ & 1 & & \\
\hline DPPH50 & -0.507 & -0.5 & -0.5 & -0.489 & -0.491 & -0.5 & -0.5 & 1 & \\
\hline ABTS50 & -0.223 & -0.216 & -0.216 & -0.203 & -0.205 & -0.216 & -0.216 & 0.954 & 1 \\
\hline
\end{tabular}

${ }^{a}$ Total phenolic content, ${ }^{\mathrm{b}}$ Total flavonoid content, Total flavonol content. ${ }^{\mathrm{d} 1} \mathrm{ABTS} \&{ }^{\mathrm{d} 2} \mathrm{ABTS}$ trolox and ascorbic acid equivalent in ABTS assay, respectively. ${ }^{\mathrm{e}} \mathrm{FRAP}$

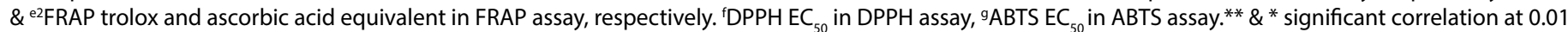
and 0.05 level, respectively (2-tailed) while without asterisk means not significant, for Table 5( A-D).

Tannins are considered as a potent anticancer agent with antioxidant properties. ${ }^{39}$ Saponins are natural detergents known to have antiinflammatory, expectorant, immune stimulating, and antineoplastic effects. They reduce blood cholesterol level by binding with cholesterol and bile salts. Once bound to saponins, bile salts are unable to form small micelles with cholesterol and thus prevent its absorption in the intestinal tract. ${ }^{40}$ Steroids found in both plants and animals have many therapeutic uses. Steroids from plants are important source of medicine having cardiotonic, antibacterial and insecticidal properties. $^{41}$
Since there were no reports on the TPC, TFC and TFlC of Alphitonia species, the results obtained for $A$. philippinensis in this study were compared to other known medicinal plants as shown in Table 3 . The TPC of $A$. philippinensis leaves in the present study was higher than those of Colubrina asiatica, ${ }^{42}$ Ginkgo biloba, ${ }^{43}$ Etlingera coccinea, ${ }^{4}$ Zizyphus oxyphylla, ${ }^{44}$ and Morus alba, ${ }^{43}$ but lower than Zizyphus spinachristi, ${ }^{45}$ Zizyphus xylopyrus, ${ }^{46}$ and Goniothalamus velutinus. ${ }^{2}$ The value of TPC for the barks was lower than those of $Z$. spina-christi ${ }^{45}$ and $G$. velutinus, ${ }^{2}$ whereas higher value was obtained for the fruits than those of Z. jujube, ${ }^{47}$ Z. mistol, ${ }^{48}$ and Z. spina-christi, ${ }^{45}$ but lower 
than Z. lotus, ${ }^{49}$ Z. oxyphylla, ${ }^{44}$ and Z. xylopyrus ${ }^{46}$ The TPC result for stems in this study was higher than that of C. asiatica, ${ }^{42}$ but lower than E. coccinea, ${ }^{4}$ and Z. oxyphylla. ${ }^{44}$ In terms of the total flavonoid content, leaves of A. philippinensis was also higher than those of Etlingera belalongensis (3.77 mg catechin equivalent $(\mathrm{CE}) / \mathrm{g}$ ), E. volutina $(7.63$ $\mathrm{mg}$ CE/g) and Zingiber pseudopungens (2.87 mg CE/g) ${ }^{50}$ The leaves also had the highest flavonol content $(4.60 \mathrm{mg} \mathrm{QE} / \mathrm{g} \mathrm{DW})$ compared to barks $(0.12 \mathrm{mg} \mathrm{QE} / \mathrm{g} \mathrm{DW})$, stems $(0.001 \mathrm{mg} \mathrm{QE} / \mathrm{g} \mathrm{DW})$ and fruits (1.82 mg QE/g DW).

Phenolic compounds from plants had been reported to show a variety of biological functions such as antioxidant, antibacterial, antiinflammatory, anticarcinogenic, antiatherosclerotic and antiviral activities. ${ }^{17,18,20}$ They also have a vital role in preventing osteoporosis, neurodegenerative disease, diabetes and major cardiovascular ailments like hypertension. ${ }^{36,38}$

Among polyphenols, flavonoids are a large group of compounds having potent antioxidant activities. The special chemical structures of flavonoids, compared with other polyphenols, such as the position of hydroxyl group, carbonyl group and double bond are responsible for their antioxidant activities. ${ }^{51}$ They have a variety of biological activities such as antibacterial, anti-inflammatory, antiallergic, antithrombotic, and vasodilatory activities. They also hamper the diffusion of free radicals by stabilizing membrane fluidity and thus prevent the peroxidation reaction. ${ }^{36}$ Flavonols such as quercetin, kaempferol, myricetin, rutin, and azaleatin, have also been reported to show antioxidant properties. ${ }^{52}$

Phenolic compounds are the constitutive products of plants and accumulate during normal growth and development. Some phenolic compounds like flavonols and flavones are formed in plant in presence of sunlight and mainly concentrated in the outer tissues. ${ }^{53}$ They are found greatly in leaves and fruits than the other plant parts. ${ }^{53-55}$ These reports supports the results of this study as A.phillipinensis has the highest phenolic contents in leaves followed by fruits, barks and stem which is in agreement with other published reports. ${ }^{4,56}$

The antioxidant capacity of different plant parts of A. phlippinensis varied significantly $(P<0.05)$ amongst them (Table 4$)$. For each assay (FRAP and ABTS), the rank of antioxidant activity, from highest to lowest was, leaves $>$ fruits $>$ barks $>$ stems. In comparison to some other known medicinal plants, leaves of A. philippinensis showed higher antioxidant activity than those of $Z$. jujuba (Rhamnaceae), Paeonia lactiflora (Paeoniaceae), Cimicifuga foetida (Ranunculaceae), Lobelia chinensis (Campanulaceae) and M. alba (Moraceae) with antioxidant capacity values of $546,85,349,26$ and $23 \mu \mathrm{mol} \mathrm{TE} / \mathrm{g}$, respectively. These plants have been reported to exhibit antispasmodic, anti-inflammatory, analgesic and anticancer effect. Their uses in the treatment of fever, stomach ache, swelling, sores and improved sleep by soothing nerves have scientifically been proven. ${ }^{5,57}$ The antioxidant activity of fruits of A. philippinensis was also higher than those of M. alba $(1.32 \mu \mathrm{mol}$ $\mathrm{TE} / \mathrm{g})$, Ligustrum lucidum of the Oleaceae $(2.34 \mu \mathrm{mol} \mathrm{TE} / \mathrm{g})$ and Gardenia jasminoides of the Rubiacea $(1.32 \mu \mathrm{mol}$ TE/g). However, its barks exhibited lower antioxidant activity than those of Cinnamomum cassia of the Lauraceae (28 mg GAE/g DW) and Magnolia officinalis of the Magnoliaceae (32 mg GAE/g DW). Similarly, the activity of stems was lower than those of Spatholobus suberectus (Leguminosae) and Dendrobium nobile (Orchidaceae) with antioxidant capacity values of $90 \mathrm{mg} \mathrm{GAE} / \mathrm{g}$ DW and $22 \mathrm{mg} \mathrm{GA}$, respectively. ${ }^{54}$

The antioxidant activities (expressed as $\mathrm{EC}_{50}$ values) of methanolic extracts of A. philippinensis in comparison to trolox and ascorbic acids as standard references, differed significantly amongst the four plant parts for DPPH (Figure 2) and ABTS (Figure 3), except for leaves and fruits. The rank from best to lowest scavengers for each assay was Trolox $>$ ascorbic acid $>$ leaves $>$ fruits $>$ barks $>$ stems. When their EC $_{50}$ values were compared with those of other species of the same Rhamnaceae family, leaves of $A$. Philippinensis has lower value (stronger antioxidant activity) than those of $A$. xerocarpus ${ }^{16}(180 \mu \mathrm{g} / \mathrm{mL})$, Colubrina Asiatica ${ }^{42}$ $(57 \mu \mathrm{g} / \mathrm{mL})$, Ziziphus mauritiana ${ }^{34}(101 \mu \mathrm{g} / \mathrm{mL})$, but higher (lower antioxidant activity) than those of $Z$. spina-christi ${ }^{34}(18 \mu \mathrm{g} / \mathrm{mL})$, and Scuitia buxifolia ${ }^{58}(30 \mu \mathrm{g} / \mathrm{mL})$. Stems of C. asiatica $^{42}(43 \mu \mathrm{g} / \mathrm{mL})$, and barks of S. buxifolia ${ }^{58}(29 \mu \mathrm{g} / \mathrm{mL})$, showed lower EC ${ }_{50}$ values than those of A. philippinensis. Similar data for fruits of species of this family were unavailable for comparison. With reference to other medicinal species of different families, leaves of $A$. philippinensis showed the highest antioxidant activity amongst Berberis integerrima and B. vulgaris of Berberidaceae $(210 \& 450 \mu \mathrm{g} / \mathrm{mL})$, Mentha piperita, Melissa officinalis and Salvia officinalis of Lamiaceae $(230,400,920 \mu \mathrm{g} / \mathrm{mL})$, Artemisia absinthium of Asteraceae $(560 \mu \mathrm{g} / \mathrm{mL})$, and Foenciculum vulgare of Apiaceae $(1060 \mu \mathrm{g} / \mathrm{mL})$. Stems, barks and fruits of A. philippinensis in this study also showed lower $\mathrm{EC}_{50}$ values than leaves of the species mentioned above. ${ }^{59}$

This study found a good correlation evidence between antioxidant content with antioxidant property and to the best of our knowledge this is the first complete reported "antioxidant profile" for A. philippinensis. TPC of leaves extract (Table 5A) showed good significant correlation with TFC $(r=0.99, p<0.05)$ but not TFlC. Both TPC and TFC showed linear correlation with ABTS and FRAP, when either trolox or ascorbic acid was used as the standard, however the correlation was significant only for FRAP. Strong negative correlations were observed for TPC, TFC with DPPH $\mathrm{EC}_{50}$ and $\mathrm{ABTS} \mathrm{EC}_{50}$, indicating that increasing TPC and TFC in leaves would increase the antioxidant activity. TFlC of the leaves extract only showed correlation with $\mathrm{DPPH} \mathrm{EC}_{50}(\mathrm{r}=0.61)$.

Unlike the leaves extract which showed no correlation between TFlC with TPC and TFC, the bark extract (Table 5B), however, showed good linear correlations between the three with $\mathrm{r}$ value 0.98 . Strong linear correlations were also observed for FRAP assays with TPC, TFC and TFLC. Of these, significant correlations was found between FRAP and TFC $(\mathrm{r}=1.00, p<0.05)$, while TPC and TFlC also showed significant negative correlations with DPPH EC E0 $_{0}(\mathrm{r}=-0.99, p<0.05$ and $\mathrm{r}=-1.00$, $p<0.01$, respectively).

As for the stem extract, except for FRAP assay using ascorbic acid as the standard, generally there were correlations between TPC, TFC, TFlC and all the antioxidant assays. However, none were significant. For the $\mathrm{DPPH}$ and $\mathrm{ABTS} \mathrm{EC}_{50}$ determination, TFC showed the highest negative correlation ( $\mathrm{r}$ value -0.98 and -0.85 ), followed by TPC ( $\mathrm{r}$ value -0.97 and -0.80 ) and TFlC ( $r$ value -0.69 and -0.36 , respectively).

Of the four extracts studied, the fruit extract (Table 5D) showed maximum correlation not only between TPC, TFC and TFlC but also with FRAP and ABTS, all giving significant correlation of $r=1.00$ and $p<0.01$ or $p<0.05$. This is in line with literature reports in which fruits

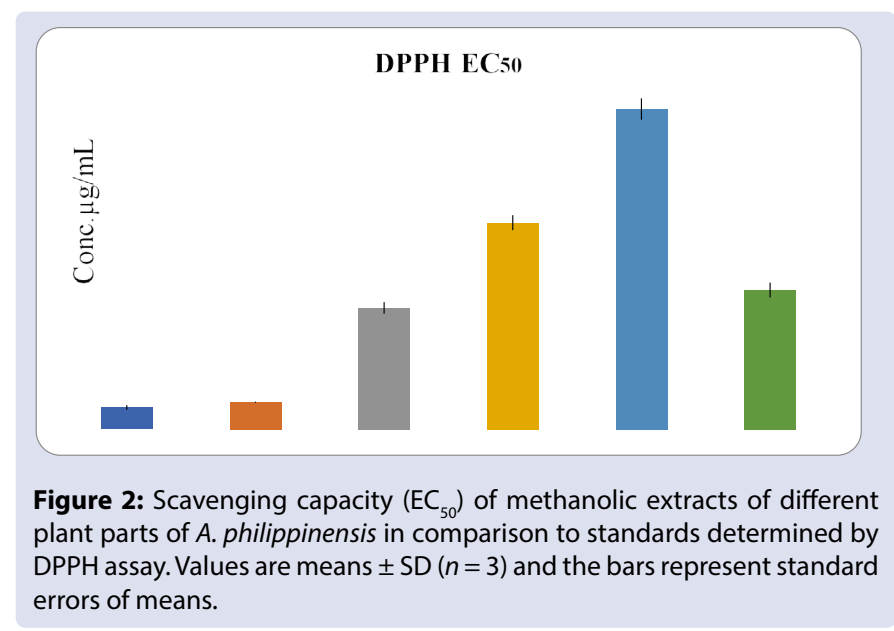




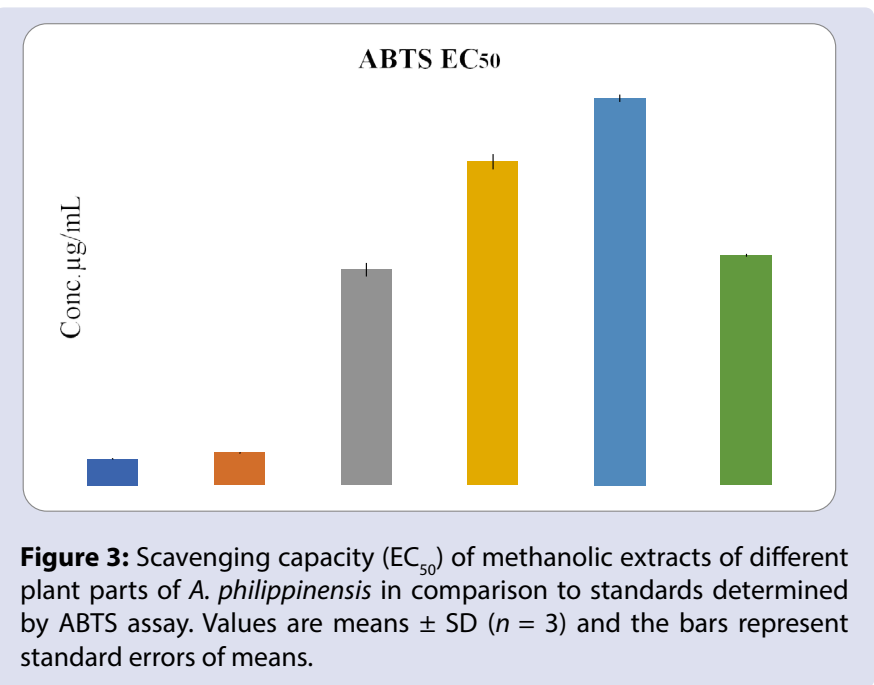

and fruit juices have been known to show high correlation between TPC and antioxidant activities. ${ }^{60,61}$ However, no correlation was observed for $\mathrm{EC}_{50}$ of DPPH and ABTS.

Among the four plant parts leaves and fruits showed highest correlation between the antioxidant contents and assays followed by barks and fruits. These variations of correlation with antioxidant contents and assays may happen due to the variation of mechanism of action, delocalization of electron, solubility and redox potential. ${ }^{27,62}$ FRAP can measure the activity of hydrophilic antioxidants, ABTS can measure both hydrophilic and lipophilic antioxidants, and DPPH can react only with those antioxidants that are soluble in organic solvents. ${ }^{2,46}$ The evaluation of antioxidant capacity of these extracts with different assay methods has made the results more reliable since it has been shown that a single method of evaluating antioxidant activity may not be sufficient as no one method will be able to fully evaluate the antioxidant property of a given sample. ${ }^{63}$ Our results are consistent with other reports ${ }^{4,26,47}$ and indicate that phenolic compounds could have a major contribution to the antioxidant property of $A$. philippinensis. This is in line with reports where high antioxidant activity is associated with high TPC and such observation is not just limited to medicinal plants, but also in wild and cultivated plants ${ }^{64}$, flour, ${ }^{65}$ seaweed, ${ }^{66}$ fruits ${ }^{67}$ etc. However, it must be noted that a report ${ }^{68}$ showed in their study that other plant constituents such as reducing carbohydrate, terpenes, ascorbates etc could also be responsible for the antioxidant activity of a given plant.

\section{CONCLUSIONS}

The results of current study showed that methanolic extracts of different plant parts (leaves, barks, stems and fruits) of $A$. philippinensis revealed the presence of cardiac glycosides, steroids, terpenoids, saponins and tannins. These phytochemicals have vital roles in modern medicines and plants containing these constituents are considered as important natural sources. Based on the antioxidant contents (TPC, TFC, TFlC) and in vitro antioxidant assays (DPPH, ABTS and FRAP), leaves of A. philippinensis showed the highest antioxidant activity followed by fruits, barks and stems. Comparative studies with different published data of some medicinal plants conclude that the leaves of $A$. philippinensis are strong source of natural antioxidants and can be used as a substitute for synthetic antioxidants in food and pharmaceutical industries to extent the shelf life of their products. A. philippinensis, known for its use in traditional medicine in Brunei Darussalam, has not been sufficiently explored. This is the first attempt and reports to evaluate its medicinal properties. Further studies on the pharmacological evaluation and the isolation of bioactive compounds of the plant are currently being carried out.

\section{ACKNOWLEDGEMENTS}

The authors would like to thank the Government of Brunei Darussalam and the Universiti Brunei Darussalam for providing scholarship and other necessary facilities to Jamiuddin Ahmed to perform this research. We wish to express our sincere thanks to Noramalina Ismail, Erum Iqbal, AFM Shahid-Ud-Daula and all laboratory staff of the Environmental and Life Sciences Programme for their assistance in different stages of this study.

\section{REFERENCES}

1. Choo C-Y, Abdullah N, Diederich M. Cytotoxic activity and mechanism of action of metabolites from the Goniothalamus genus. Phytochemistry Reviews. 2014:13(4):835-51.

2. Iqbal E, Salim KA, Lim LB. Phytochemical screening, total phenolics and antioxidant activities of bark and leaf extracts of Goniothalamus velutinus (Airy Shaw) from Brunei Darussalam. Journal of King Saud University-Science. 2015;27(3):224-32

3. Kaufman PB, Cseke LJ, Warber S, Duke JA, Brielmann HL. Natural products from plants. 1998:CRC Press Inc.

4. Shahid-Ud-Daula AFM, Kamariah AS, Lim LBL, Ahmad N. Phytochemical screening, antioxidant, and antimicrobial activities of leaves, stems, and rhizomes of Etlingera coccinea (Blume) S. Sakai \& Nagam. International Journal of Pharmacognosy and Phytochemical Research. 2015;7(5):873-83.

5. Evans WC. Trease and Evans' Pharmacognosy 16 ed. 2009: Elsevier Health Sciences.

6. Gan R-Y, Xu X-R, Song F-L, Kuang L, Li H-B. Antioxidant activity and total phenolic content of medicinal plants associated with prevention and treatment of cardiovascular and cerebrovascular diseases. Journal of Medicinal Plants Research. 2010;4(22):2438-44.

7. Joy P, Thomas J, Mathew S, Skaria BP. Medicinal plants. Tropical Horticulture 1998;2:449-632.

8. Sofowora A. Research on medicinal plants and traditional medicine in Africa The Journal of Alternative and Complementary Medicine. 1996;2(3):365-72.

9. Van Wyk B-E, Wink M. Medicinal plants of the world. An Illustrated Scientific Guide to Important Medicinal Plants and their Uses. 2004, Timber Press, Portland.

10. Alam MN, Bristi NJ, Rafiquzzaman M. Review on in vivo and in vitro methods evaluation of antioxidant activity. Saudi Pharmaceutical Journal. 2013:21(2):14352.

11. Aruoma OI. Free radicals, oxidative stress, and antioxidants in human health and disease. Journal of the American Oil Chemists' Society. 1998;75(2):199212

12. Bagchi K, Puri S. Free radicals and antioxidants in health and disease: a review Eastern Mediterranean health journal. 1998;4(2):350-60.

13. Mishra PK, Shukla R, Singh P, Prakash B, Dubey NK. Antifungal and antiaflatoxigenic efficacy of Caesulia axillaris Roxb. essential oil against fung deteriorating some herbal raw materials, and its antioxidant activity. Industrial Crops and Products. 2012;36(1):74-80.

14. Muhammad D, Hubert J, Lalun N, Renault JH, Bobichon $H$, Nour M, et al. Isolation of flavonoids and triterpenoids from the fruits of Alphitonia Neocaledonica and evaluation of their anti-oxidant, anti-tyrosinase and cytotoxic activities. Phytochemical Analysis. 2015;26(2):137-44.

15. Correa E, Jaramillo C, Manchester S, Gutierrez M. A fruit and leaves of Rhamnaceous affinities from the late Cretaceous (Maastrichtian) of Colombia. American Journal of Botany. 2010;97(1):71-9

16. Muhammad D, Lalun N, Bobichon H, Debar ELM, Gangloff SC, Nour M, et al. Triterpenoids from the leaves of Alphitonia xerocarpus Baill and their biological activity. Phytochemistry. 2016;129:45-57.

17. Dunstan CA, Liu B, Welch CJ, Perera P, and Bohlin L. Alphitol, a phenolic substance from Alphitonia zizyphoides which inhibits prostaglandin biosynthesis in vitro. Phytochemistry, 1998. 48(3): 495-497.

18. Somasundaram J. Anti-ulcer activity of aqueous extract of Alphitonia zizyphoides bark in experimental rats. International Journal of Pharmacotherapy. 1(3):28-33.

19. Thomson LA, Thaman RR. Alphitonia zizyphoides (toi). Traditional trees of pacific islands: Their culture, environment, and use: permanent agriculture resources, 2006 
Ahmed, et al:: Evaluation of Antioxidant Activity and Phytochemical Screening of Leaves, Barks, Stems and Fruits of Alphitonia philippinensis (Rhamnaceae) From Brunei Darussalam

20. Jou SJ, Chen CH, Guh JH, Lee CN, Lee SS. Flavonol glycosides and cytotoxic triterpenoids from Alphitonia philippinensis. Journal of the Chinese Chemical Society. 2004;51(4):827-34

21. Chlopicka J, Pasko P, Gorinstein S, Jedryas A, Zagrodzki P. Total phenolic and total flavonoid content, antioxidant activity and sensory evaluation of pseudocereal breads. LWT-Food Science and Technology. 2012;46(2):548-555.

22. Lin J-Y, Tang C-Y. Determination of total phenolic and flavonoid contents in selected fruits and vegetables, as well as their stimulatory effects on mouse splenocyte proliferation. Food Chemistry. 2007;101(1):140-7.

23. Kumaran A, Karunakaran RJ. In vitro antioxidant activities of methanol extracts of five Phyllanthus species from India. LWT-Food Science and Technology. 2007:40(2):344-52

24. Abdul-Wahab N-Z, Shahar S, Abdullah-Sani H, Pihie AHL, Ibrahim N. Antioxidant, antibacterial and antiviral properties of Goniothalamus umbrosus leaves methanolic extract. African Journal of Microbiology Research. 2011;5(20):313843.

25. Lobo VC, Phatak A, Chandra N. Antioxidant and free radical scavenging activity of Hygrophila schulli (Buch.-Ham.) Almeida and Almeida Seeds Adv Biores. 2010;1(2):72-8.

26. Thaipong K, Boonprakob U, Crosby K, Cisneros-Zevallos L, Byrne DH. Comparison of ABTS, DPPH, FRAP, and ORAC assays for estimating antioxidant activity from guava fruit extracts. Journal of Food Composition and Analysis. 2006;19(6):669-75

27. Fidrianny I, Ayu D, Hartati R. Antioxidant capacities, phenolic, flavonoid and carotenoid content of various polarities extracts from three organs of Sechium edule (Jacq.) Swartz. Journal of Chemical and Pharmaceutical Research. 2015;7(5):914-20

28. Boussahel S, Speciale A, Dahamna S, Amar Y, Bonaccorsi I, Cacciola F, et al. Flavonoid profile, antioxidant and cytotoxic activity of different extracts from Algerian Rhamnus alaternus L. bark. Pharmacognosy magazine. 2015;11(Suppl 1):S102.

29. Do QD, Angkawijaya AE, Tran-Nguyen PL, Huynh LH, Soetaredjo FE, Ismadji $\mathrm{S}$, et al. Effect of extraction solvent on total phenol content, total flavonoid content, and antioxidant activity of Limnophila aromatica. Journal of Food and Drug Analysis. 2014;22(3):296-302.

30. Mokrani A, Madani K. Effect of solvent, time and temperature on the extraction of phenolic compounds and antioxidant capacity of peach (Prunus persica L.) fruit. Separation and Purification Technology. 2016;162:68-76.

31. Mahendra C, Manasa G, Kiran B, Murali M, Girish H, Sudarshana M Phytochemical, histochemical, and antibacterial screening of Chenopodium anthelminticum L. Journal of Herbs, Spices \& Medicinal Plants. 2017;23(3):18392.

32. Iloki-Assanga SB, Lewis-Luján LM, Lara-Espinoza CL, Gil-Salido AA, FernandezAngulo D, Rubio-Pino JL, et al. Solvent effects on phytochemical constituent profiles and antioxidant activities, using four different extraction formulations for analysis of Bucida buceras L. and Phoradendron californicum. BMC Research Notes. 2015:8(1):396.

33. Padalia H, Poptani R, Chanda S. Evaluation of in Vitro antioxidant properties of solvent extracts of selected medicinal plants and their synergistic efficacy. Journal of Herbs, Spices \& Medicinal Plants. 2017:1-13.

34. Abalaka ME, Mann A, Adeyemo SO. Studies on in-vitro antioxidant and free radical scavenging potential and phytochemical screening of leaves of Ziziphus mauritiana L. and Ziziphus spina-christi L. compared with ascorbic acid. Journal of Medical Genetics and Genomics. 2011;3(2):28-34.

35. Talmale SA, Bhujade AM, Patil MB. Phytochemical analysis of stem bark and root bark of Zizyphus Mauritiana. International Journal of Innovative Science, Engineering \& Technology. 2014;1(4).

36. Cook N and Samman S. Flavonoids-chemistry, metabolism, cardioprotective effects, and dietary sources. The Journal of Nutritional Biochemistry. 1996;7(2):66-76.

37. Kren V, Martínková L. Glycosides in medicine: "The role of glycosidic residue in biological activity". Current Medicinal Chemistry. 2001;8(11):1303-28.

38. Pandey KB, Rizvi SI. Plant polyphenols as dietary antioxidants in human health and disease. Oxidative Medicine and Cellular Longevity. 2009;2(5):270-8.

39. Li H, Wang Z, LiuY. Review in the studies on tannins activity of cancer prevention and anticancer. Journal of Chinese Medicinal Materials. 2003;26(6):444.

40. Shi J, Arunasalam K, Yeung D, Kakuda Y, Mittal G, Jiang Y. Saponins from edible legumes: Chemistry, processing, and health benefits. Journal of Medicinal Food. 2004;7(1):67-78.
41. Bagrov AY, Shapiro JI, Fedorova OV. Endogenous cardiotonic steroids: physiology, pharmacology, and novel therapeutic targets. Pharmacological Reviews. 2009;61(1):9-38.

42. Desai N, Gaikwad DK. Phytochemical screening and in-vitro antioxidant activities of Colubrina asiatica Brong. Journal of Chemical and Pharmaceutical Research. 2014;6(9):282-8.

43. Song F-L, Gan R-Y, Zhang Y, Xiao Q, Kuang L, Li H-B. Total phenolic contents and antioxidant capacities of selected Chinese medicinal plants. International Journal of Molecular Sciences. 2010;11(6):2362-72.

44. Ahmad R, Ahmad N, Naqvi AA. "Ziziphus oxyphylla": Ethnobotanical, ethnopharmacological and phytochemical review. Biomedicine \& Pharmacotherapy. 2017;91:970-98.

45. Muddathir A, Yamauchi K, Batubara I, Mohieldin E, Mitsunaga T. Anti-tyrosinase, total phenolic content and antioxidant activity of selected Sudanese medicinal plants. South African Journal of Botany. 2017;109:9-15.

46. Raghavendra $H$, Prashith KT, Akarsh SM, Ashwini H. Phytochemical analysis, antifungal and antioxidant activity of leaf and fruit of Zizyphus xylopyrus (Retz.) Willd.(Rhamnaceae). Science, Technology and Arts Research Journal 2015;4(4):83-8.

47. Kou X, Chen O, Li X, Li M, Kan C, Chen B, et al. Quantitative assessment of bioactive compounds and the antioxidant activity of 15 jujube cultivars. Food Chemistry. 2015;173:1037-44.

48. Cardozo M, Ordonez R, Alberto M, Zampini I, Isla M. Antioxidant and antiinflammatory activity characterization and genotoxicity evaluation of Ziziphus mistol ripe berries, exotic Argentinean fruit. Food Research International. 2011;44(7):2063-71.

49. Hammi KM, Jdey A, Abdelly C, Majdoub H, Ksouri R. Optimization of ultrasoundassisted extraction of antioxidant compounds from Tunisian Zizyphus lotus fruits using response surface methodology. Food Chemistry. 2015;184:80-9.

50. Sabli F, Mohamed M, Rahmat A, Ibrahim H, Abu Bakar M. Antioxidant properties of selected Etlingera and Zingiber species (Zingiberaceae) from Borneo Island. International Journal of Biological Chemistry. 2012;6(1):1-9.

51. Arora A, Byrem TM, Nair MG, Strasburg GM. Modulation of liposomal membrane fluidity by flavonoids and isoflavonoids. Archives of Biochemistry and Biophysics. 2000;373(1):102-9.

52. Kalita P, Tapan BK, PalTK, Kalita R. Estimation of total flavonoids content (TFC) and anti-oxidant activities of methanolic whole plant extract of Biophytum sensitivum Linn. Journal of Drug delivery and Therapeutics. 2013;3(4):33-7.

53. Herrmann K. On the occurrence of flavonol and flavone glycosides in vegetables. Zeitschrift für Lebensmittel-Untersuchung und Forschung. 1988;186(1):1-5.

54. Cai Y, Luo Q, Sun M, Corke H. Antioxidant activity and phenolic compounds of 112 traditional Chinese medicinal plants associated with anticancer. Life Sciences. 2004;74(17):2157-84.

55. Li S, Li S-K, Gan R-Y, Song F-L, Kuang L, Li H-B. Antioxidant capacities and total phenolic contents of infusions from 223 medicinal plants. Industrial Crops and Products. 2013;51:289-98.

56. Kubola J, Siriamornpun S. Phenolic contents and antioxidant activities of bitte gourd (Momordica charantia L.) leaf, stem and fruit fraction extracts in vitro. Food Chemistry. 2008;110(4):881-90.

57. Damiano S, Forino M, De A, Vitali LA, Lupidi G, Taglialatela-Scafati O. Antioxidant and antibiofilm activities of secondary metabolites from Ziziphus jujuba leaves used for infusion preparation. Food Chemistry. 2017;230:24-9

58. Boligon AA, Pereira RP, Feltrin AC, Machado MM, Janovik V, Rocha JBT, et al Antioxidant activities of flavonol derivatives from the leaves and stem bark of Scutia buxifolia Reiss. Bioresource Technology. 2009;100(24):6592-8.

59. Rezaeian S, Pourianfar HR, Janpoor J. Antioxidant properties of several medicinal plants growing wild in northeastern Iran. Asian J Plant Sci Res. 2015;5:63-8

60. Gardner PT, White TA, McPhail DB, Duthie GG. The relative contributions of vitamin $\mathrm{C}$, carotenoids and phenolics to the antioxidant potential of fruit juices. Food Chemistry. 2000;68(4):471-4.

61. Gil MI, Tomás-Barberán FA, Hess-Pierce B, Kader AA. Antioxidant capacities, phenolic compounds, carotenoids, and vitamin $\mathrm{C}$ contents of nectarine, peach, and plum cultivars from California. Journal of Agricultural and Food Chemistry. 2002;50(17):4976-82.

62. Ku KM, Kim HS, Kim SK, Kang Y-H. Correlation analysis between antioxidant activity and phytochemicals in Korean colored corns using principal component analysis. Journal of Agricultural Science. 2014;6(4):1. 
Ahmed, et al.: Evaluation of Antioxidant Activity and Phytochemical Screening of Leaves, Barks, Stems and Fruits of Alphitonia philippinensis (Rhamnaceae) From Brunei Darussalam

63. Moharram $\mathrm{H}$, Youssef M. Methods for determining the antioxidant activity: A review. Alexandria Journal of Food Science and Technology. 2014;11(1):31-42.

64. Piluzza G, Bullitta S. Correlations between phenolic content and antioxidant properties in twenty-four plant species of traditional ethnoveterinary use in the Mediterranean area. Pharmaceutical Biology. 2011;49(3):240-7.

65. Li Y, Ma D, Sun D, Wang C, Zhang J, Xie Y, et al. Total phenolic, flavonoid content, and antioxidant activity of flour, noodles, and steamed bread made from different colored wheat grains by three milling methods. The Crop Journal. 2015;3(4):328-34
66. Mohamed N, Abdullah A. Comparison of total phenolic content and antioxidant activity of Kappaphycus alvarezii from Langkawi and Semporna. in AIP Conference Proceedings. 2016. AIP Publishing.

67. Lutz M, Hernández J, Henríquez $\mathrm{C}$. Phenolic content and antioxidant capacity in fresh and dry fruits and vegetables grown in Chile. CyTA-Journal of Food. 2015;13(4):541-7.

68. Babbar N, Oberoi HS, Uppal DS, Patil RT. Total phenolic content and antioxidant capacity of extracts obtained from six important fruit residues. Food Research International. 2011:44(1):391-6.

\section{GRAPHICAL ABSTRACT}

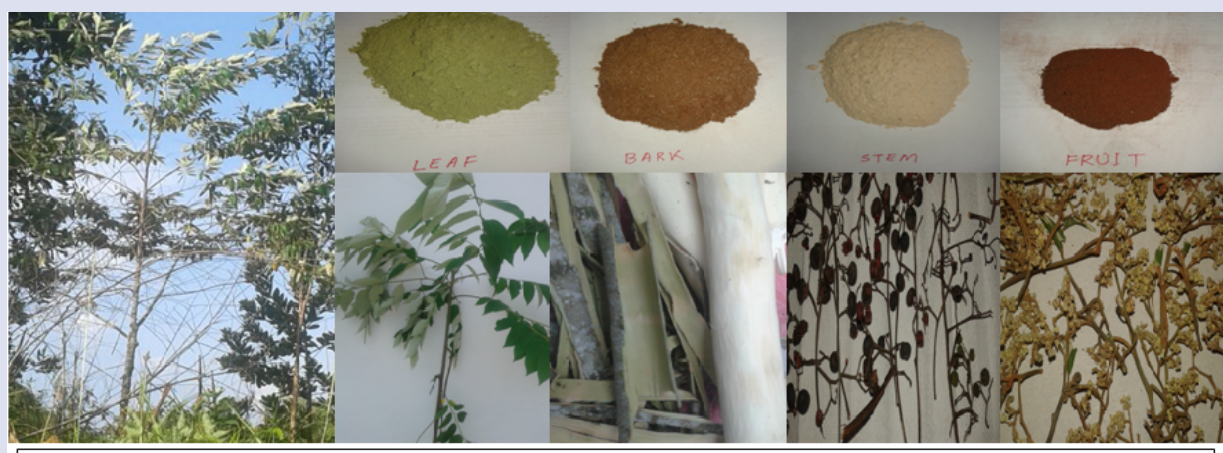

A. philippinensis leaves, barks, stems \& fruits

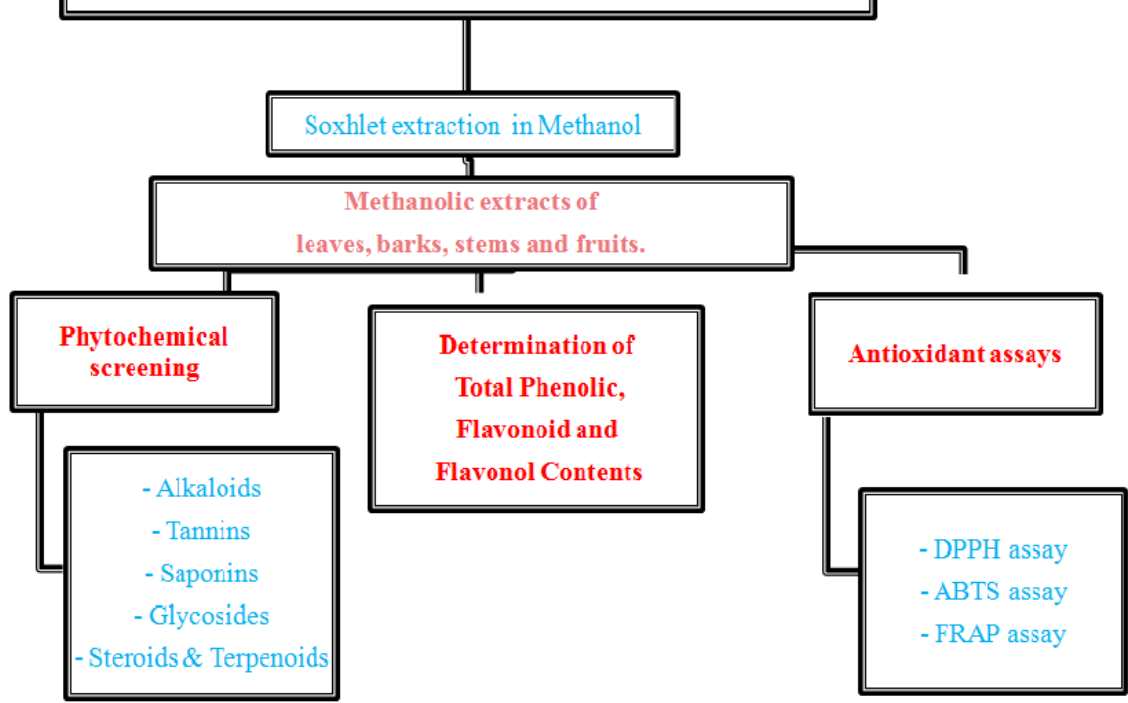

\section{SUMMARY}

- Alphitonia philippinensis Braid (Rhamnaceae) is vernacularly known by the Malays in Brunei Darussalam as "balik angin", which leaves are used as traditional medicine by the inhabitant for the treatment of stomachaches and herbal bath for women to regain strength after delivery.

- Methanolic extracts of different plant parts (leaves, barks, stems and fruits) of $A$. philippinensis revealed the presence of cardiac glycosides, steroids, terpenoids, saponins and tannins.

- Based on the antioxidant contents (TPC, TFC, TFIC) and in vitro antioxidant assays (DPPH, ABTS and FRAP), leaves of $A$. philippinensis showed the highest antioxidant activity followed by fruits, barks and stems. 


\section{ABOUT AUTHORS}

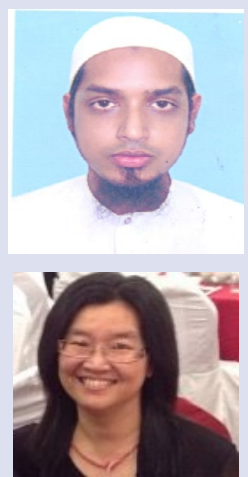

Jamiuddin Ahmed, Research fellow (PhD) in Department of Environmental and Life Sciences, Faculty of Science, Universiti Brunei Darussalam and, Associate Professor, Department of Pharmacy, Noakhali science and Technology University, Sonapur-3814, Bangladesh. Current Research: Antioxidant, Phytochemicals and Bioactive compound isolation.

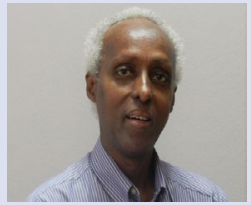

Linda B.L. Lim, Associate Professor, Department of Chemical Sciences, Faculty of Science, Universiti Brunei Darussalam, Tungku Link Road, Bandar Seri Begawan, BE 1410, Brunei Darussalam. Research interests: Medicinal and Aromatic Plants, Adsorption of pollutants using natural adsorbents.

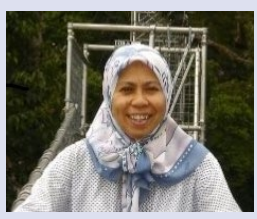

Abdalla Mohamed Jama, Professor, Environmental and Life Sciences, Faculty of Science, Universiti Brunei Darussalam, Tungku Link Road, Bandar Seri Begawan, BE 1410, Brunei Darussalam. Current research projects: Activation and signaling of Bruton's tyrosine kinase (Btk), Gene therapy for HIV. Research interests: Molecular basis of disease, cell and gene therapy, cellular signaling.

Kamariah Abu Salim, Retired Senior Lecturer, Environmental and Life Sciences, Faculty of Science, Universiti Brunei Darussalam, Tungku Link Road, Bandar Seri Begawan, BE 1410, Brunei Darussalam. Research interests: Antioxidant, Phytochemicals, Tropical forest.

Cite this article: Ahmed J, Salim KA, Lim LBL, Jama AM. Evaluation of Antioxidant Activity and Phytochemical Screening of Leaves, Barks, Stems and Fruits of Alphitonia philippinensis (Rhamnaceae) From Brunei Darussalam. Pharmacog J. 2019;11(5):95161. 